\title{
SHOULD WE TREAT PAIN IN THE ELDERLY PALLIATIVE CARE CANCER PATIENTS DIFFERENTLY?
}

\author{
Marin Golčić ${ }^{1}$, Renata Dobrila-Dintinjana ${ }^{1}$, Goran Golčić ${ }^{1}$, Ivana Plavšić ${ }^{2}$, \\ Lidija Gović-Golčić ${ }^{3}$, Borislav Belev ${ }^{4}$, Domagoj Gajski ${ }^{5,6,7}$ and Krešimir Rotim ${ }^{5,6,8}$ \\ ${ }^{1}$ Department of Radiotherapy and Oncology, Rijeka University Hospital Centre, Rijeka, Croatia; \\ ${ }^{2}$ Primorje-Gorski Kotar County Health Centre, Rijeka, Croatia; \\ ${ }^{3}$ General Practice Office, Rijeka, Croatia; \\ ${ }^{4}$ Department of Oncology, Zagreb University Hospital Centre, Zagreb, Croatia; \\ ${ }^{5}$ Department of Neurosurgery, Sestre milosrdnice University Hospital Centre, Zagreb, Croatia; \\ ${ }^{6}$ Department of Anatomy and Physiology, University of Applied Health Sciences, Zagreb, Croatia; \\ ${ }^{7}$ University of Zagreb, School of Dental Medicine, Zagreb, Croatia; \\ ${ }^{8}$ Faculty of Medicine, Josip Juraj Strossmayer University of Osijek, Osijek, Croatia
}

\begin{abstract}
SUMMARY - Opioids are considered the cornerstone of pain management in palliative care. Available data suggest that older patients use different analgesics and lower opioid doses compared to younger patients. However, it has not been elucidated yet whether such dosing is associated with worse pain levels or shorter survival in the palliative care setting. We evaluated the relationship among pain scores, quality of life, opioid dose, and survival in palliative care cancer patients in a hospice setting. A total of 137 palliative care cancer patients were analyzed prospectively. We divided patients into two groups using the age of 65 as a cut-off value. Younger patients exhibited significantly higher pain ratings (5.14 vs. 3.59, $\mathrm{p}=0.01$ ), although older patients used almost $20 \mathrm{mg}$ less oral morphine equivalent $(\mathrm{OME})$ on arrival $(\mathrm{p}=0.36)$ and $55 \mathrm{mg} \mathrm{OME} /$ day less during the last week $(\mathrm{p}=0.03)$. There were no differences in survival between the two groups (17.36 vs. 17.58 days). The elderly patients also used nonsteroidal analgesics less often and paracetamol more often. Hence, using lower opioid doses in older palliative care cancer patients does not result in worse pain rating, and could be a plausible approach for pain management in this patient group.
\end{abstract}

Key words: Elderly patients; Hospice care; Opioids; Pain management; Palliative care

\section{Introduction}

Treatment of pain is one of the most important goals of palliative care, with opioids considered one of the four essential drugs in the care of the dying, along with antipsychotics, anxiolytics, and antimuscarinics ${ }^{1}$. However, the use of opioids in the hospice setting is a controversial issue, as studies have shown that opioid use is associated with both longer and shorter surviv-

Correspondence to: Marin Golčic, $M D, P h D$, Department of Radiotherapy and Oncology, Rijeka University Hospital Centre, Krešimirova 42, HR-51000 Rijeka, Croatia

E-mail: marin.golcic@gmail.com

Received June 30, 2020, accepted August 9, 2020 $\mathrm{al}^{2,3}$, whereas some researchers demonstrated no effect of opioids on survival ${ }^{4}$. Opioids, however, remain the cornerstone of pain management in palliative care, while the use of non-opioid analgesia is rarely recommended, partly due to the potentially life-threatening side effects, especially in patients with many comorbidities $^{5}$. Despite these recommendations and lack of research demonstrating their safety, nonsteroidal antiinflammatory drugs (NSAID) and paracetamol are still among the most commonly used drugs in the care of the dying ${ }^{6,7}$.

Along with controversies regarding the choice of analgesics, there are indications that elderly palliative care patients require different pain management than 
younger patients due to decreased renal excretion and hepatic metabolism, greater number of comorbidities, and higher risk of polypharmacy and adverse drug effects. Additionally, although some researchers suggest that older patients experience similar or even less pain than younger patients, pain management in the elderly is often unsatisfactor $\mathrm{y}^{8-15}$.

In our previous retrospective study conducted in the same hospice, we found older patients to have used lower opioid doses and suggested opiophobia or lower needs of opioids in the elderly due to altered opioid metabolism as the possible culprits ${ }^{16-18}$. Our findings were supported by a similar research, which found that the elderly experienced similar pain intensity as younger patients but required up to $71 \mathrm{mg}$ less of parenteral morphine equivalent a day ${ }^{19}$. However, the research was retrospective and did not evaluate differences in survival or use of additional or adjuvant analgesics $^{20}$, which could explain the need for lower opioid doses.

In this research, we tried to answer the question of whether the use of lower opioid doses in elderly cancer patients is associated with worse pain levels and quality of life.

\section{Patients and Methods}

The study was conducted in Marija Krucifiksa Kozulić Hospice in Rijeka, Croatia, which is the only hospice in the country and hosts 14 beds. The research was part of a larger study and was performed from September 2016 until August 2017. We included 137 patients who had to be over age 18 and had to sign an informed consent. Exclusion criteria included delirium, unable or refusing to provide informed consent, or cognitive state that prevented appropriate evaluation of pain scales. All the patients had undergone specialist evaluation according to which no active treatment was left anymore and life expectancy was less than three months. Although there is no universal definition of the elderly, we used 65 years of age as a typical cut-off value to define elderly patients ${ }^{21}$. The Hospice Ethics Committee approved this research, which was performed in line with the highest medical and ethical standards.

The patients were evaluated within the first two days of admission. The evaluation consisted of the $\mathrm{Eu}-$ ropean Organization for Research and Treatment of
Cancer Quality of Life Questionnaire Core $15 \mathrm{Pal}$ (EORTC QLQ-C15-PAL) and Edmonton Symptom Assessment System (ESAS) 22,23. Demographic data and the Palliative Performance Scale (PPS) were recorded from the charts. Only the subset score from the pain and quality of life variables on both questionnaires were included in this analysis ${ }^{24}$. ESAS is an 11item scale, where 0 denotes no pain and 10 denotes the worst possible pain. EORTC QLQ-C15-PAL estimates the frequency of pain during the week prior to examination, ranging from 1 (not at all) to 4 (very much).

Medications analyzed further in the text were prescribed on schedule and were extracted from medical charts. Opioid doses were converted to the oral morphine equivalents (OME, $\mathrm{mg} / \mathrm{day}$ ), while corticosteroid doses were converted to methylprednisolone equivalent doses ${ }^{25,26}$. We did not analyze difference in the doses of anxiolytics, NSAIDs or antidepressants due to difficulties with calculating equivalent doses and differences in half-life.

Descriptive statistics was used to analyze demographic data and included means, medians, and standard deviations. Mann Whitney test was used to determine differences between patient groups. The $\chi^{2}-$ test was used to test differences in frequency between the groups, while differences in survival were assessed using the log-rank test and Kaplan-Meier method. All statistical procedures were performed by use of Statistica 12 software (StatSoft, Tulsa, USA).

\section{Results}

A total of 137 cancer patients were included in the study, 78 male and 59 female patients, mean age $71.8 \pm 9.3$ years. The patients were divided into younger and older patient groups, using age 65 as the cut-off value. The most common cancers were lung $(n=34,24.8 \%)$, gastrointestinal $(\mathrm{n}=25,18.2 \%)$ and hepatobiliary cancers $(\mathrm{n}=17,12.4 \%)$. Lung and gastrointestinal cancers were most common in both groups of patients, although the third most common cancer in younger patients was urologic cancer $(n=4,14.3 \%)$. There were no significant differences between the two groups according to PPS, gender, level of education, discharge status, metastatic status, whether pain was present upon arrival, or number of days spent in the hospice (17.36 vs. 17.58 days in younger and older patients, respectively) (Table 1). 
Table 1. Demographic data $(N=137)$

\begin{tabular}{|c|c|c|c|}
\hline & All patients & Younger patients ${ }^{a}$ & Older patients ${ }^{a}$ \\
\hline Number of patients (\%) & $137(100)$ & $28(20.4)$ & $109(79.6)$ \\
\hline Mean age, years $( \pm \mathrm{SD})$ & $71.8(9.3)$ & $58.6(6.7)$ & $75.2(6.3)$ \\
\hline $\mathrm{PPS}( \pm \mathrm{SD})$ & $33.1(12.5)$ & $37.1(15.6)$ & $32.1(11.5)$ \\
\hline Number of days in hospice $( \pm \mathrm{SD})$ & $17.54(19.7)$ & $17.36(19.8)$ & $17.58(19.8)$ \\
\hline \multicolumn{4}{|l|}{ Gender } \\
\hline Female (\%) & $59(43.1)$ & $11(39.3)$ & $48(44.0)$ \\
\hline \multicolumn{4}{|l|}{ Level of education } \\
\hline Elementary (\%) & $35(25.6)$ & $5(17.9)$ & $30(27.5)$ \\
\hline High school (\%) & $74(54.0)$ & $17(60.7)$ & $57(52.3)$ \\
\hline College (\%) & $24(17.5)$ & $6(21.4)$ & $18(16.5)$ \\
\hline Not specified (\%) & $4(2.9)$ & $0(0)$ & $4(3.7)$ \\
\hline \multicolumn{4}{|l|}{ Metastatic status } \\
\hline Metastasis present (\%) & $109(79.6)$ & $24(85.7)$ & $85(77.9)$ \\
\hline \multicolumn{4}{|l|}{ Discharge status } \\
\hline Death (\%) & $115(83.9)$ & $22(78.6)$ & $93(85.3)$ \\
\hline Discharged (\%) & $22(16.1)$ & $6(21.4)$ & $16(14.7)$ \\
\hline \multicolumn{4}{|l|}{ Pain present on admission } \\
\hline Yes (\%) & $72(52.6)$ & $16(57.1)$ & $56(51.4)$ \\
\hline No $(\%)$ & $64(46.7)$ & $12(42.9)$ & $52(47.7)$ \\
\hline Unknown & $1(0.7)$ & $0(0)$ & $1(0.9)$ \\
\hline
\end{tabular}

${ }^{\text {aB }}$ Based on the cut-off value of 65 years of age; PPS = Palliative Performance Scale

Table 2. Pain and quality of life scores on admission ( $N=137)$

\begin{tabular}{|l|l|l|l|l|}
\hline Category & All patients & Younger $^{c}$ & Older $^{*}$ & p-value $^{*}$ \\
\hline Pain, QLQ-C15-PAL subset, mean \pm SD & $55.59 \pm 25.82$ & $60.71 \pm 29.82$ & $54.28 \pm 24.68$ & 0.24 \\
Quality of life, QLQ-C15-PAL subset, mean \pm SD & $32.35 \pm 18.34$ & $30.95 \pm 21.14$ & $32.72 \pm 17.64$ & 0.65 \\
Pain, ESAS subset, mean \pm SD & $3.86 \pm 2.58$ & $5.14 \pm 2.33$ & $3.59 \pm 2.55$ & $\mathbf{0 . 0 1}$ \\
Wellbeing, ESAS subset, mean \pm SD & $6.74 \pm 1.85$ & $7.13 \pm 1.79$ & $6.65 \pm 1.89$ & 0.27 \\
\hline
\end{tabular}

QLQ-C15-PAL subset = Quality of Life Questionnaire Core 15 PAL, from 0 to 100, higher values indicate higher level of pain or higher quality of life; ESAS subset = Edmonton Symptom Assessment System, from 0 to 10, higher values indicate higher level of pain or lower wellbeing; "based on the cut-off value of 65 years of age; $\mathrm{SD}=$ standard deviation; bold figure denotes statistical significance

No differences were recorded in the pain and quality of life subset scores in the EORTC QLQ-C15 PAL and the wellbeing score in the ESAS. However, younger patients reported significantly higher pain ratings measured on the ESAS questionnaire (5.14 vs. $3.59, \mathrm{p}=0.01)$ (Table 2).

On admission, the most commonly used opioids in regular therapy were tramadol $(\mathrm{n}=58)$, fentanyl transdermal patches $(n=45)$, buprenorphine transdermal patches $(n=20)$ and oral morphine $(n=14)$, while paracetamol $(n=39)$, ibuprofen $(n=13)$ and diclofenac $(n=4)$ were the most commonly used non-opioid analgesics. On average, older patients used almost $20 \mathrm{mg}$ OME/day less on admission $(\mathrm{p}=0.36)$ and $55 \mathrm{mg}$ $\mathrm{OME} /$ day less during the last week $(\mathrm{p}=0.03)$ as compared with younger patients. Additionally, fewer older patients used opioids at all, both on admission $(68.8 \%$ vs. $85.7 \%)$ and during the last week (75.2\% vs. $89.3 \%)$, 
Table 3. Use of analgesics $(N=137)$

\begin{tabular}{|c|c|c|c|c|}
\hline Category & All patients & Younger $^{a}$ & Older* & p-value \\
\hline \multicolumn{5}{|l|}{ Opioids } \\
\hline OME $\mathrm{mg} /$ day on arrival, mean $($ mean $\pm \mathrm{SD})$ & $100.21(92.18)$ & $115.19(83.39)$ & $95.42(94.85)$ & 0.36 \\
\hline $\mathrm{OME} \mathrm{mg} /$ day in last week, mean (mean $\pm \mathrm{SD}$ ) & $122.96(115.06)$ & $165.61(142.22)$ & $109.95(102.95)$ & 0.03 \\
\hline \multicolumn{5}{|c|}{ Classical analgesics } \\
\hline Opioids, initial (\%) & $99(72.3)$ & $24(85.7)$ & $75(68.8)$ & 0.07 \\
\hline Opioids, final (\%) & $107(78.1)$ & $25(89.3)$ & $82(75.23)$ & 0.11 \\
\hline Paracetamol, initial (\%) & $39(28.5)$ & $3(10.7)$ & $36(33.0)$ & 0.02 \\
\hline Paracetamol, final (\%) & $38(27.7)$ & $3(10.7)$ & $35(32.1)$ & 0.02 \\
\hline NSAID, initial (\%) & $20(14.6)$ & $8(28.6)$ & $12(11.0)$ & 0.02 \\
\hline NSAID, final (\%) & $22(16.1)$ & $8(28.6)$ & $14(12.8)$ & 0.04 \\
\hline \multicolumn{5}{|l|}{ Adjuvant analgesics } \\
\hline Corticosteroids, initial (\%) & $40(29.2)$ & $8(28.6)$ & $32(29.4)$ & 0.93 \\
\hline Corticosteroids, final (\%) & $45(32.8)$ & $9(32.1)$ & $36(33.0)$ & 0.93 \\
\hline Antipsychotics, initial (\%) & $29(21.2)$ & $6(21.4)$ & $23(21.1)$ & 0.97 \\
\hline Antipsychotics, final (\%) & $44(32.1)$ & $9(32.1)$ & $35(32.1)$ & 0.99 \\
\hline Anxiolytics, initial (\%) & $83(60.6)$ & $17(60.7)$ & $66(60.6)$ & 0.99 \\
\hline Anxiolytics, final (\%) & $81(59.1)$ & $16(57.1)$ & $65(59.6)$ & 0.81 \\
\hline Antidepressants, initial (\%) & $21(15.3)$ & $6(21.4)$ & $15(13.8)$ & 0.32 \\
\hline Antidepressants, final (\%) & $22(16.0)$ & $6(21.4)$ & $16(14.7)$ & 0.39 \\
\hline
\end{tabular}

$\mathrm{OME}=$ oral morphine equivalent; NSAID = nonsteroidal anti-inflammatory drug; "based on the cut-off value of 65 years of age; SD = standard deviation; bold figures denote statistical significance

although the difference did not reach statistical significance (Table 3).

Elderly cancer patients used NSAIDs less often, both initially ( $28.6 \%$ vs. $11.0 \%, \mathrm{p}=0.02)$ and in the last week $(28.6 \%$ vs. $12.8 \%, \mathrm{p}=0.04)$, while they used paracetamol more often at both time points $(10.7 \%$ vs. $33.0 \%, \mathrm{p}=0.02$ initially, and $10.7 \%$ vs. $32.1 \%, \mathrm{p}=0.02$ during the last week). There were no differences in the dosage of paracetamol $(1083 \mathrm{mg} /$ day vs. $994 \mathrm{mg} /$ day, $\mathrm{p}=0.80$ ), haloperidol (2.92 vs. $2.41 \mathrm{mg} /$ day, $\mathrm{p}=0.59$ ), or methylprednisolone equivalent doses (30.5 mg vs. 50.1 $\mathrm{mg}, \mathrm{p}=0.18$ ) between the younger and older patient groups. Even when observing the whole study population, there was positive correlation of $\mathrm{r}=0.245(\mathrm{p}<0.05)$ between age and the initial opioid dose. There was no between-group difference in the frequency of using corticosteroids, antipsychotics, anxiolytics and antidepressants, either on admission or during the last week (Table 3).

There was a correlation between the quality of life and pain score in both EORTC QLQ-C15 PAL (r=
-0.31) and ESAS ( $\mathrm{r}=0.5)(\mathrm{p}<0.05)$. Interestingly, the higher opioid dose was associated with worse pain ratings on both ESAS $(r=0.31, p<0.05)$ and EORTC QLQ-C15 PAL $(r=0.28, p<0.05)$. The use of pain medication also seemed to form a pattern, as the use of paracetamol and NSAIDs showed a significant negative association $(r=-0.21)$, while the use of paracetamol showed a positive correlation to opioid use $(\mathrm{r}=0.32)$. No association was found between the use of NSAIDs and opioids ( $\mathrm{r}=0.02)$.

Regarding difference in survival, the patients that used NSAIDs on admission had longer survival compared to patients who did not (26.7 vs. 15.9 days, $\mathrm{p}=0.001$ ), while no difference was recorded for paracetamol use (14.9 vs. 18.6 days, $\mathrm{p}=0.72)$.

\section{Discussion}

Concerning the use of opioids, paracetamol and NSAIDs, they all have controversies in palliative care due to fear of the potentially life-threatening side ef- 
fects. The use of opioids is lately under particular scrutiny due to the presence of major opioid crisis, and is reinforced by the fact that up to $25 \%$ of hospice patients have substance use disorders, often associated with the usage of higher levels of opioids ${ }^{27,28}$. However, treatment with opioids is dependent on the medicolegal responsibilities of prescribers ${ }^{29}$, hence it may vary significantly among different populations.

Age is an important factor in pain management and choice of analgesics. Although only a few studies explored the issue, pain levels do not seem to be higher in older patients despite using lower doses of opioids. This phenomenon may be explained by the more advanced coping strategies, questionnaires being more sensitive in younger population, difference in the use of additional analgesics, as well as some specific cultural factors ${ }^{8,15}$. Our previously published research on 790 cancer patients in the same hospice showed that patients older than 65 used significantly less opioids on arrival as compared with younger patients (146.2 vs. $86.9 \mathrm{mg}$ OME/day); however, we did not analyze pain scores or quality of life ${ }^{16}$.

Hence, in this study, we aimed to answer the question of whether using fewer opioids is associated with higher pain levels or worse quality of life in the elderly. We used the definition of the elderly as people older than 65 , although we recognize the need to update that definition, especially in the areas such as palliative care ${ }^{26}$.

Both groups of patients had very similar demographic characteristics (Table 1). Younger patients reported higher levels of pain compared to older patients, although no differences were found in the quality of life scores. Regarding the use of analgesics, there was a trend showing the older cancer patients to have used opioids less frequently (85.7\% vs. 68.8\%) and in lower doses (115 mg vs. $95 \mathrm{mg}$ OME/day) but the difference did not reach statistical significance in this population. The difference in the doses of opioids between the groups reached significance during the last week (165 vs. $109 \mathrm{mg}$ OME/day), although no data are available on pain scores. There were no differences in the use of anxiolytics, antipsychotics, or corticosteroids between the two groups either. However, we did show that the elderly used NSAIDs significantly less often (28.6 vs. $11.0 \%)$ and paracetamol significantly more often (33.0\% vs. 10.7\%), although there was no difference in the dose of paracetamol. Such results suggest that the use of paracetamol might be a plausible option for se- lected elderly cancer patients instead of opioids or NSAIDs.

Despite differences in pain management, there were no differences in discharge status or survival between the two groups (Table 1). Additionally, although NSAIDs are not recommended frequently in the terminal phase due to their side effects such as cardiotoxicity and gastrointestinal bleeding, we did not find shorter survival either with these analgesics or with paracetamo ${ }^{13}$. Such findings could suggest that these drugs are safe to use in a hospice setting for selected patients, although the lack of information regarding renal or hepatic comorbidities might significantly influence our results.

There are certain limitations of the study that we must address. We performed a single-center study on Caucasian patients, and due to the concept of the study, we could not assess causality but only association. Additionally, we have no data regarding renal or hepatic reserve, since invasive measures including drawing blood are rarely used in a hospice setting, and only a minority of patients present recent blood analysis results. This information could significantly impact survival, especially in patients using NSAIDs, but was unavailable in our hospice population. A selection bias was also present, as less than $50 \%$ of patients were eligible to participate in the study or were well enough for questionnaire assessment. However, our data could be used to generate hypotheses and design a prospective study.

\section{Conclusion}

Our data suggest that there is a difference in pain management between younger and older cancer patients. Older patients used opioids and NSAIDs less often and paracetamol more often. However, younger patients reported worse pain scores, with no difference in the quality of life or survival. Hence, the data suggest that the principle "start low, go slow" must be used on opioid titration in the elderly ${ }^{14}$ and that the use of paracetamol could be a plausible option for pain control in selected cancer patients instead of opioids.

\section{References}

1. Lindqvist O, Lundquist G, Dickman A, Bükki J, Lunder U, Hagelin CL, et al. Four essential drugs needed for quality care of the dying: a Delphi-study based international expert consen- 
sus opinion. J Palliat Med. 2013 Jan;16(1):38-43. http://dx.doi. org/10.1089/jpm.2012.0205.

2. Good PD, Ravenscroft PJ, Cavenagh J. Effects of opioids and sedatives on survival in an Australian inpatient palliative care population. Intern Med J. 2005 Sep;35(9):512-7. http://dx.doi. org/10.1111/j.1445-5994.2005.00888.x.

3. Portenoy RK, Sibirceva U, Smout R, Horn S, Connor S, Blum $\mathrm{RH}$, et al. Opioid use and survival at the end of life: a survey of a hospice population. J Pain Symptom Manage. 2006 Dec;32(6): 532-40. http://dx.doi.org/10.1016/j.jpainsymman.2006.08.003.

4. Azoulay D, Jacobs JM, Cialic R, Mor EE, Stessman J. Opioids, survival, and advanced cancer in the hospice setting. J Am Med Dir Assoc. 2011 Feb;12(2):129-34.http://dx.doi.org/10.1016/j. jamda.2010.07.012.

5. Davis A, Robson J. The dangers of NSAIDs: look both ways. Br J Gen Pract. 2016 Apr;66(645):172-3. http://dx.doi.org/ 10.3399/bjgp16X684433.

6. McNeil MJ, Kamal AH, Kutner JS, Ritchie CS, Abernethy AP. The burden of polypharmacy in patients near the end of life. J Pain Symptom Manage. 2016 Feb;51(2):178-83.e2. http:// dx.doi.org/10.1016/j.jpainsymman.2015.09.003.

7. Masman AD, van Dijk M, Tibboel D, Baar FP, Mathôt RA. Medication use during end-of-life care in a palliative care centre. Int J Clin Pharm. 2015 Oct;37(5):767-75. http://dx.doi. org/10.1007/s11096-015-0094-3.

8. Olden AM, Holloway R, Ladwig S, Quill TE, van Wijngaarden E. Palliative care needs and symptom patterns of hospitalized elders referred for consultation. J Pain Symptom Manage. 2011 Sep;42(3):410-8. http://dx.doi.org/10.1016/j. jpainsymman.2010.12.005.

9. Desbiens NA, Wu AW, Broste SK, Wenger NS, Connors Jr AF, Yasui $\mathrm{Y}$, et al. Pain and satisfaction with pain control in seriously ill hospitalized adults: findings from the SUPPORT research investigations. For the SUPPORT investigators. Study to Understand Prognoses and Preferences for Outcomes and Risks of Treatment. Crit Care Med. 1996 Dec;24(12):1953-61.

10. McMillan SC. The relationship between age and intensity of cancer-related symptoms. Oncol Nurs Forum. 1989 Mar-Apr; 16(2):237-41.

11. Schmader KE, Baron R, Haanpää ML, Mayer J, O'Connor AB, Rice ASC, et al. Treatment considerations for elderly and frail patients with neuropathic pain. Mayo Clin Proc. 2010 Mar;85 (3 Suppl):S26-32. http://dx.doi.org/10.4065/mcp.2009.0646.

12. Bernabei R, Gambassi G, Lapane K, Landi F, Gatsonis C, Dunlop R, et al. Management of pain in elderly patients with cancer. SAGE Study Group. Systematic assessment of geriatric drug use via epidemiology. JAMA. 1998 Jun;279(23):1877-82.

13. Dalacorte RR, Rigo JC, Dalacorte A. Pain management in the elderly at the end of life. N Am J Med Sci. 2011 Aug;3(8):34854. http://dx.doi.org/10.4297/najms.2011.3348

14. Prostran M, Vujović KS, Vučković S, Medić B, Srebro D, Divac $\mathrm{N}$, et al. Pharmacotherapy of pain in the older population: the place of opioids. Front Aging Neurosci. 2016 Jun;8:144. http:// dx.doi.org/10.3389/fnagi.2016.00144.
15. Teunissen SC, de Haes HC, Voest EE, de Graeff A. Does age matter in palliative care? Crit Rev Oncol Hematol. 2006 Nov;60 (2):152-8. http://dx.doi.org/10.1016/ j.critrevonc.2006.06.002.

16. Golčić M, Dobrila-Dintinjana R, Golčić G, Čubranić A. The impact of combined use of opioids, antipsychotics, and anxiolytics on survival in the hospice setting. J Pain Symptom Manage. 2018 Jan;55(1):22-30. http://dx.doi.org/10.1016/j.jpainsymman.2017.08.004.

17. Bond M. Pain education issues in developing countries and responses to them by the International Association for the Study of Pain. Pain Res Manag. 2011 Nov-Dec;16(6):404-6. http:// dx.doi.org/10.1155/2011/654746.

18. Smith HS. Opioid metabolism. Mayo Clin Proc. 2009 Jul;84 (7):613-24. http://dx.doi.org/10.1016/S0025-6196(11)60750-7.

19. Viganó A, Bruera E, Suarez-Almazor ME. Age, pain intensity, and opioid dose in patients with advanced cancer. Cancer. 1998 Sep;83(6):1244-50.

20. Lussier D, Huskey AG, Portenoy RK. Adjuvant analgesics in cancer pain management. Oncologist. 2004;9(5):571-91. http: //dx.doi.org/10.1634/theoncologist.9-5-571.

21. Singh S, Bajorek B. Defining 'elderly' in clinical practice guidelines for pharmacotherapy. Pharm Pract (Granada). 2014 Oct;12(4):489. http://dx.doi.org/10.4321/s1886-3655201400 0400007.

22. Echteld MA, Deliens L, Onwuteaka-Philipsen B, Klein M, van der Wal G. EORTC QLQ-C15-PAL: the new standard in the assessment of health-related quality of life in advanced cancer? Palliat Med. 2006 Jan;20(1):1-2. http://dx.doi.org/ 10.1191/0269216306pm1090ed.

23. Bruera E, Kuehn N, Miller MJ, Selmser P, Macmillan K. The Edmonton Symptom Assessment System (ESAS): a simple method for the assessment of palliative care patients. J Palliat Care. 1991 Summer;7(2):6-9.

24. Golčić M, Dobrila-Dintinjana R, Golčić G, Pavlović-Ružić I, Stevanović A, Gović-Golčić L. Quality of life in a hospice: a validation of the Croatian version of the EORTC QLQ-C15PAL. Am J Hosp Palliat Care. 2018 Aug;35(8):1085-90. http://dx.doi.org/10.1177/ 1049909118760781.

25. Twycross R, Wilcock A, Howard P. Palliative Care Formulatory. $5^{\text {th }}$ Edition. Palliativedrugs.com Ltd; 2014.

26. Becker DE. Basic and clinical pharmacology of glucocorticosteroids. Anesth Prog. 2013 Spring;60(1):25-31. http://dx.doi. org/10.2344/0003-3006-60.1.25.

27. Gabbard J, Jordan A, Mitchell J, Corbett M, White P, Childers J. Dying on hospice in the midst of an opioid crisis: what should we do now? Am J Hosp Palliat Care. 2019 Apr;36 (4):273-81. http://dx.doi.org/10.1177/1049909118806664.

28. Bruera E, Moyano J, Seifert L, Fainsinger RL, Hanson J, Suarez-Almazor M. The frequency of alcoholism among patients with pain due to terminal cancer. J Pain Symptom Manage. 1995 Nov;10(8):599-603.

29. Habek D, Šklebar I. Medico-legal responsibility in management of acute and chronic pain in obstetrics. Acta Clin Croat. 2019 Jun;58(Suppl 1):114-7. http://dx.doi.org/10.20471/acc. 2019.58.s1.17 
Sažetak

\section{TREBAMO LI LIJEČITI BOL U STARIJIH PALIJATIVNIH ONKOLOŠKIH BOLESNIKA DRUKČIJE?}

\section{Golčic, R. Dobrila-Dintinjana, G. Golčić, I. Plavšić, L. Gović-Golčić, B. Beler, D. Gajski i K. Rotim}

Opioidi se smatraju jednim od osnovnih lijekova u liječenju boli u palijativnoj skrbi. Dostupni podaci ukazuju na to da stariji bolesnici uzimaju drukčije analgetike uz niže doze opioida u usporedbi s mlađim bolesnicima. Međutim, nije razjašnjeno utječe li takvo doziranje opioida na lošije liječenje razine boli ili kraće preživljenje u uvjetima palijativne skrbi. Analizirali smo odnos razine boli, kvalitete života, doze opioida i preživljenja u palijativnih onkoloških bolesnika koji su bili hospitalizirani u hospiciju. Ukupno je 137 palijativnih bolesnika analizirano prospektivno. Bolesnici su podijeljeni u dvije skupine pri čemu se dob od 65 godina uzimala kao granica između skupina. Mlađi bolesnici su izražavali višu razinu boli prilikom dolaska u hospicij (5,14 prema 3,59, p=0,01), iako su stariji bolesnici koristili gotovo $20 \mathrm{mg}$ manje oralnog morfij ekvivalenta (OME) na dan dolaska te čak $55 \mathrm{mg}$ OME manje na dan tijekom zadnjeg tjedna $(\mathrm{p}=0,03)$. Nije bilo razlika u preživljenju između dviju skupina bolesnika (17,36 prema 17,58 dana). Starija skupina bolesnika također je nesteroidne antireumatike uzimala rjeđe, a paracetamol češće od mlađe skupine. Uzimanje nižih doza opioida u starijih onkoloških bolesnika u palijativnoj skrbi nije rezultiralo lošijom razinom boli pa bi to mogao biti razuman pristup liječenju boli u ovoj skupini bolesnika.

Ključne riječi: Stariji bolesnici; Hospicijska skrb; Opioidi; Liječenje boli; Palijationa skrb 